\title{
Rubblization: A Practical, Cost Effective and Sustainable Option for Repairing Deteriorated Airfield Pavement in the Empty Quarter Desert of Saudi Arabia
}

\author{
Waseem Ahmad Khatri1, Mohammed Al Mehthel', Sami Al Ghamdi', Nezar Al Khalifa² \\ ${ }^{1}$ Consulting Services Department, Saudi Arabian Oil Company, Dhahran, Kingdom of Saudi Arabia \\ ${ }^{2}$ Oil Facilities Projects Department, Saudi Arabian Oil Company, Dhahran, Kingdom of Saudi Arabia \\ Email: waseem.khatri@aramco.com
}

How to cite this paper: Khatri, W.A., Al Mehthel, M., Al Ghamdi, S. and Al Khalifa, N. (2021) Rubblization: A Practical, Cost Effective and Sustainable Option for Repairing Deteriorated Airfield Pavement in the Empty Quarter Desert of Saudi Arabia. Open Journal of Civil Engineering, 11, 216-234. https://doi.org/10.4236/ojce.2021.112014

Received: May 23, 2021

Accepted: June 26, 2021

Published: June 29, 202

Copyright $\odot 2021$ by author(s) and Scientific Research Publishing Inc. This work is licensed under the Creative Commons Attribution International License (CC BY 4.0).

http://creativecommons.org/licenses/by/4.0/

\section{(c) (i) Open Access}

\begin{abstract}
Rubblization technique has been extensively used to repair the damaged concrete pavement and has proven successful in developed countries like the US and Europe. It has not been fully adopted in developing region like the Middle East and this paper presents the design and construction challenges posed while assessing damaged concrete runway in empty quarter of Saudi Arabia. A number of design options for repairs for runway pavement were considered and rubblization was chosen as a preferred option for repair. This paper includes the consideration for the assessment and adoption of the concrete rubblized modulus value using the falling weight deflectometer, optimization of the tests for the whole runway using the Heavy Weight Deflectometer HWD testing to replace pits, safely working around the utilities, reasonable assumption of drop height of the pavement and installation of utility conduits in the rubblized layer. Findings of the paper demonstrates resolving technical issues which are not very well covered in the Federal Aviation Authority (FAA) EB-66 such as the additional test strips, minimum areas of rubblization for assessment using test pits, drop in the height of concrete surface and fixing of utilities in rubblized pavement. The case study demonstrates that the rubblization can be successfully carried out in remote locations like empty quarter of Saudi Arabia with carefully carried out detailed site investigations, adopting correct assumed design rubblization modulus, quality control using HWD, protection of utilities while rubblizing and use of polymer modified asphalt for successful project deployment.
\end{abstract}




\section{Keywords}

Rubblization, Reinforced Concrete Pavement, Test Pits, Reflective Cracking, Modulus, Rubblization Modulus, and Super Pave, Heavy Weight

Deflectometer (HWD), FAARFIELD, Federal Aviation Authority (FAA)

\section{Introduction}

Rehabilitation of existing pavement is one of the greatest pavement priorities facing transportation and aviation industry due to ageing existing and damaged pavement infrastructure. The use of hot-mix asphalt (HMA) overlays presents a long-term and economical solution to the pavement rehabilitation challenge. HMA overlays increase the structural capacity of the existing pavement system and improve the long-term functional pavement performance including ride, noise reduction, splash and spray, friction, and general appearance.

Rubblization involves breaking the concrete pavement into pieces. The sizes of the broken pieces usually range from sand size to $75 \mathrm{~mm}$ (3 in.) at the surface and 305 to $381 \mathrm{~mm}$ (12 to $15 \mathrm{in}$.) on the bottom of the rubblized layer. The rubblized PCC layer behaves like a high-quality granular base layer and responds as an interlocked unbound layer reducing the existing PCC to a material comparable to a high strength aggregate base course. This loss of structure must be accounted for in the HMA overlay design thickness as demonstrated in this project a total of $120,000 \mathrm{~m}^{2}$ concrete pavement was rubblized, including the taxiway areas [1].

Rubblization provides a cost-effective method to repair the existing pavement and extend the life of the pavement to a further 20 or 40 years based on the design criteria. It addresses the issue of reflective cracking, which is a major concern while using overlay construction over rigid pavements. A rubblization process was carried out to repair an airfield pavement at one of Saudi Aramco's aviation facilities, which has served its useful life.

The research provides details of an airfield rehabilitation project where an existing pavement was damaged due to continuous loading and environmental factors. The pavement served its intended design life of 20 years. Maintaining the pavement was impractical and also expensive. The objective of this research is to increase the awareness of rubblization technology in the Kingdom of Saudi Arabia and widely in the Middle East in relation to the feasibility, thickness design/material characterization, quality assurance criteria and methods, construction/equipment and challenges faced. In addition, additional QC checks are proposed to be included in the FAA Engineering Brief (EB) 66 "Rubblized Portland Cement Concrete Base Course" to ensure that the assessment includes the use of non-destructing and efficient methods like Heavy Weight Deflectometer (HWD) and the sieve analysis rather than only relying on the test pit and strip only [2]. 


\section{Reflective Cracking Issues with Asphalt Overlay on Rigid Pavement}

Reflective cracking in the overlay construction above the rigid pavement is a primary concern for pavement engineers. Reflection cracks are primarily caused by tensile stresses in the asphalt layer, which are induced by the expansion and contraction of the underlying Portland Cement Concrete (PCC) pavement in response to temperature changes. An illustration of the development and propagation of reflection cracking is presented, which shows the development and the different stages of the crack development in Figure $1 \&$ Figure 2.

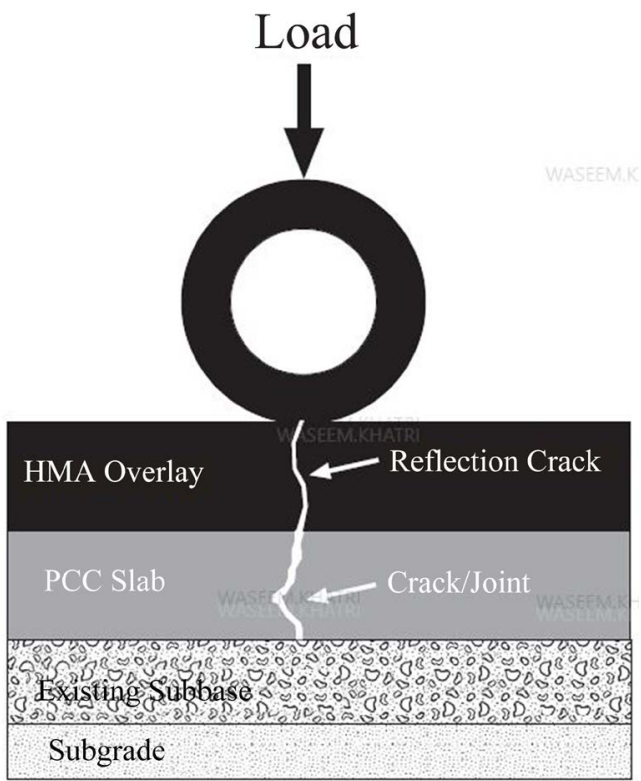

Figure 1. Reflection crack distress [1].

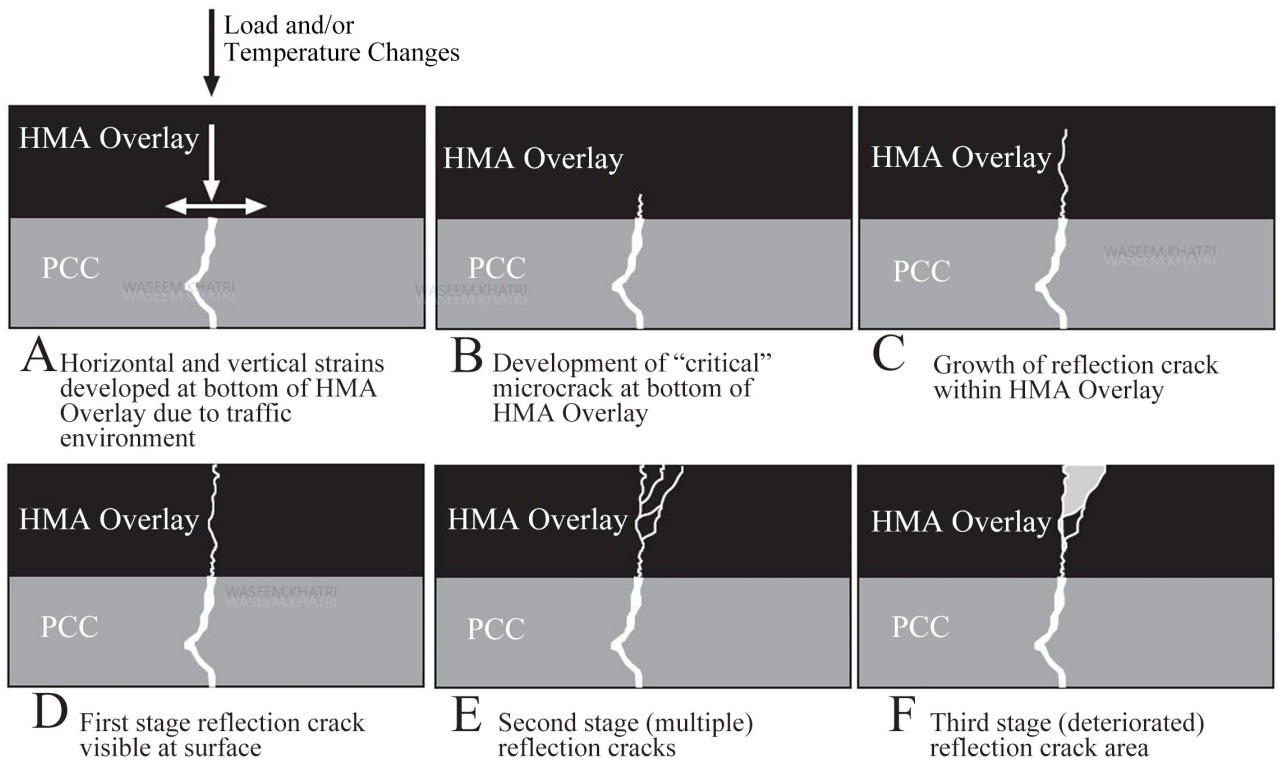

Figure 2. Growth mechanism associated with reflection cracking. 
The cracks form at the bottom of the asphalt layer, above a joint or a crack, and propagate vertically to the surface. These reflection cracks, which begin as a pattern of narrow, difficult-to-seal cracks that mirror the joints and cracks in the underlying concrete pavement, permit water to enter the pavement, triggering early deterioration of the overlay, which increases life-cycle costs and reduces the useful life of the pavement [3].

Reflection cracking can also result from shear stresses created by differential deflection between the approach and end slabs. In either case, when the stress exceeds the strength of the asphalt overlay, a crack begins and eventually propagates to the surface.

Over the years, a wide variety of techniques has been proposed to eliminate, delay, or lessen the severity of the reflection cracking problem. These include the use of bond breakers, reinforcement in the overlay, stress-absorbing membranes and interlayers, waterproofing treatments, stronger and thicker overlays, and saw-and-seal procedures. These solutions yielded mixed success and/or inconclusive results [4].

There are three techniques, as highlighted below, which have proven to be most effective in repairing the damaged PCC pavement and address the issue of reflective cracking. These techniques are crack and seat, break and seat and rubblization where an overlay can be constructed after application of one of the treatments. All methods can reduce the issue of reflective cracking with varying degree, with rubblization being most effective [5].

Rubblization is the process of converting the old concrete pavement into small, interconnected pieces, which serves as base course for the new asphalt overlay pavement. A properly rubblized pavement will entirely remove the slab action and remove the reflective cracking issue [6]. Rubblization is suited for both reinforced and unreinforced concrete pavement. It can also be used on continuously reinforced pavements.

The objective of rubblization is to eliminate reflection cracking in the HMA overlay by the total destruction of the existing slab action [7]. Rubblization is applicable when there is minimal slab integrity and structural capacity of the original Joint Reinforced concrete pavement (JRCP). It has also been used successfully for rehabilitation of other PCC pavement types. Typically, the slab is reduced to small pieces and diminished to "a high-strength granular base.

\section{Project Details-Airfield in Empty Quarter of Saudi Arabia}

An airport runway located in the remote Rub' al-Khali (“Empty Quarter") desert in Saudi Arabia started its operation in 1997. The location is remote and the airport is the most effective and practical way for transportation. The length and width of the runway are 3048 and 30 meters, respectively, with unpaved hardened shoulders of 7.5 meters wide on each side. The number of aircraft using the airport runway includes around 30 flights a week (landing/tack off) of B737-800. 
The annual movement of the aircraft traffic is 1560/annum.

The existing runway was constructed using reinforced concrete pavement and was constructed in 1997 and served for over 20 years. As shown below in Figure 3 which was produced from the existing archived drawings, existing reinforced concrete pavement was $300 \mathrm{~mm}$ thick with a layer of welded reinforcement supported by $230 \mathrm{~mm}$ aggregate base course on top of $2.5 \mathrm{~m}$ compacted dune sand fill. Control and construction joints were spaced at 5 and $30 \mathrm{~m}$ intervals, respectively.

The pavement started showing distress within few years of construction and mainly at the joint area with concrete curling, corner breaking, delamination, sealant damage and spalling at other locations. These distresses were repaired at regular interval with shallow and deep patches as required. Figures 4-9 show the patches, joint sealant damage and curling of slabs.

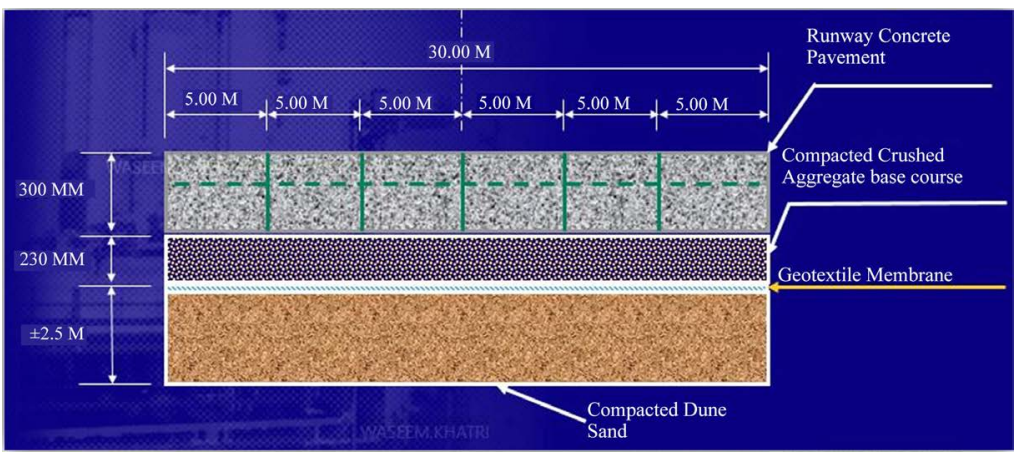

Figure 3. Cross section of the runway (developed by authors from as built drawings).

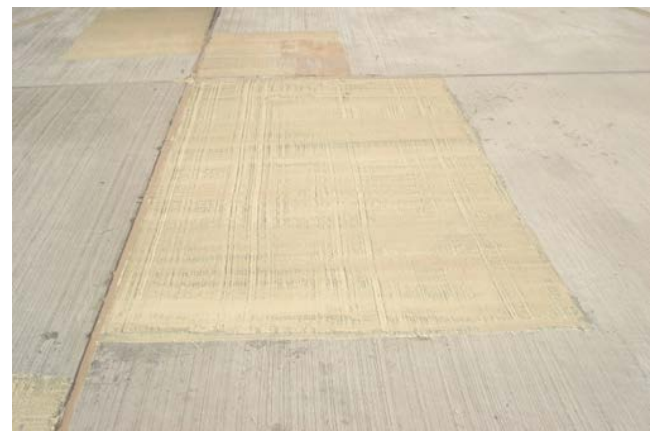

Figure 4. Conceret patche repaired (large size).

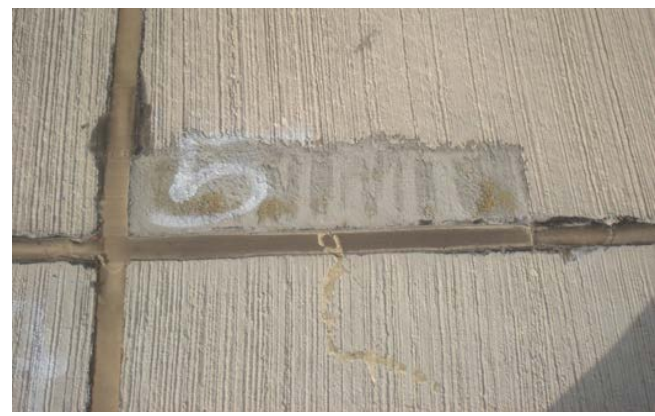

Figure 5. Conceret patch repaired (smaller size) with deformed joint sealant. 


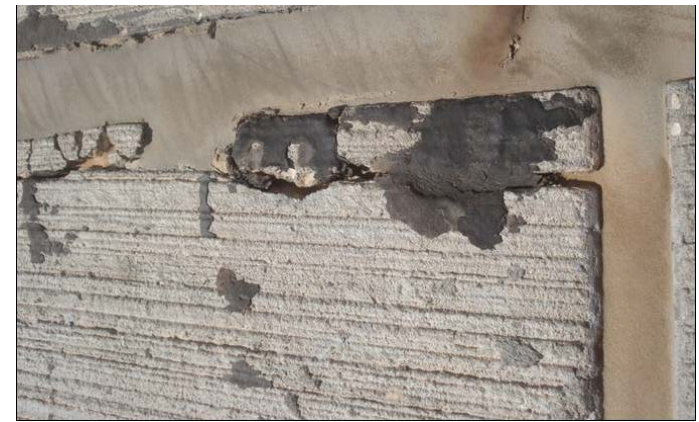

Figure 6. Deformed joint sealant crack patching.

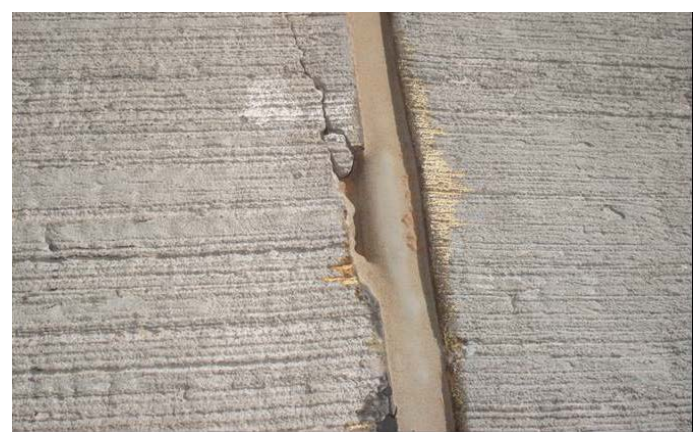

Figure 7. Joint and sealant damage.

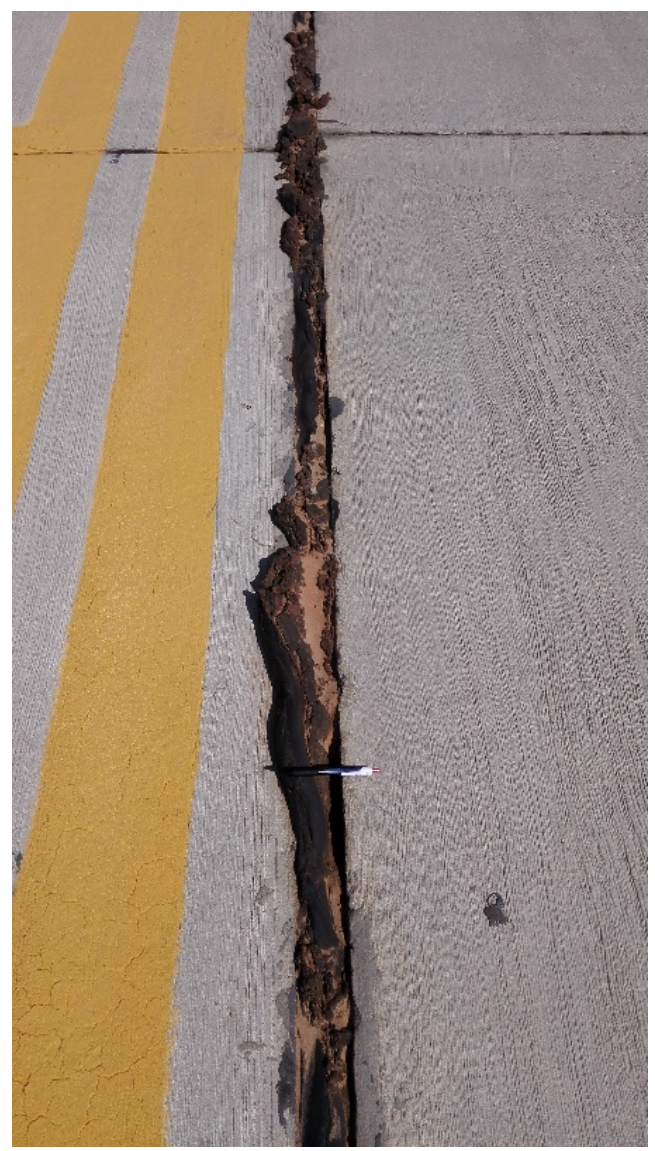

Figure 8. Joint sealant damage due to heat. 


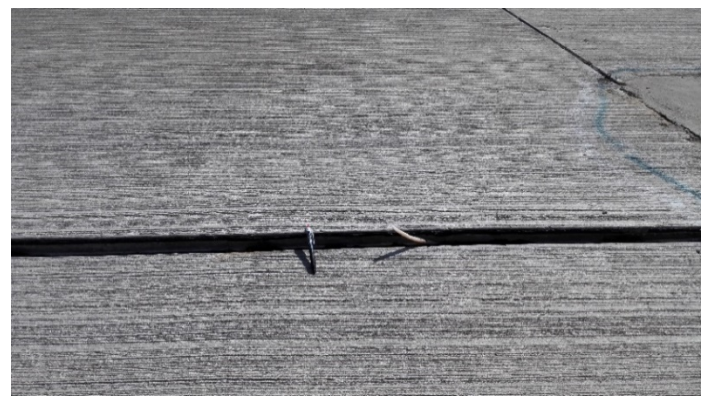

Figure 9. Curling of slabs and poor sealant condition.

After assessment on site, the following were identified as the main causes of the observed concrete deterioration:

- Improper types and detailing of dowel bars at the joint;

- Accumulation of blowing sand dunes in the joints and preventing their movement;

- Higher temperature range between day and nights.

The ongoing maintenance of the runway was not only expensive but was also disruptive to the operations of the flights with a risk of foreign object debris (FOD) [8] causing damage to the aircraft. To address the issue and come up with a permanent solution a comprehensive assessment was carried out and put in place the options for the repair and replacement of the deteriorating pavement.

\section{Evaluation of Options Considered}

Five options were considered; these were do nothing, continue with routine repairs, complete replacement, complete replacement using concrete, concrete overlay, asphalt overlay and volumetric (rapid set) and rubblization. Rubblization was selected as a preferred option to proceed as it offered sustainable, economical and durable option when compared to listed options.

\section{Results and Discussions}

\subsection{Pavement Design and Rubblized Modulus}

Designing the structural HMA overlay thickness for rubblized layer is difficult to assume, as the resulting structure is neither a true rigid pavement nor a true flexible pavement. Based on the initial test results carried out it was evident that the concrete was deteriorated at joints but the overall concrete was still in reasonable condition to allow rubblization. The average compressive strength of 50 Mpa (7251 psi) was achieved through coring [9].

With reference to above Figure 10, a quick check was carried out to assess if the pavement can be rubblized.

Based on Figure 10, the sub-grade values provide the indication to select appropriate technique. For example, a lower CBR subgrade value of three with thicker slab and aggregate base coursed of more than $300 \mathrm{~mm}$ (12 inches) can be rubblized. 


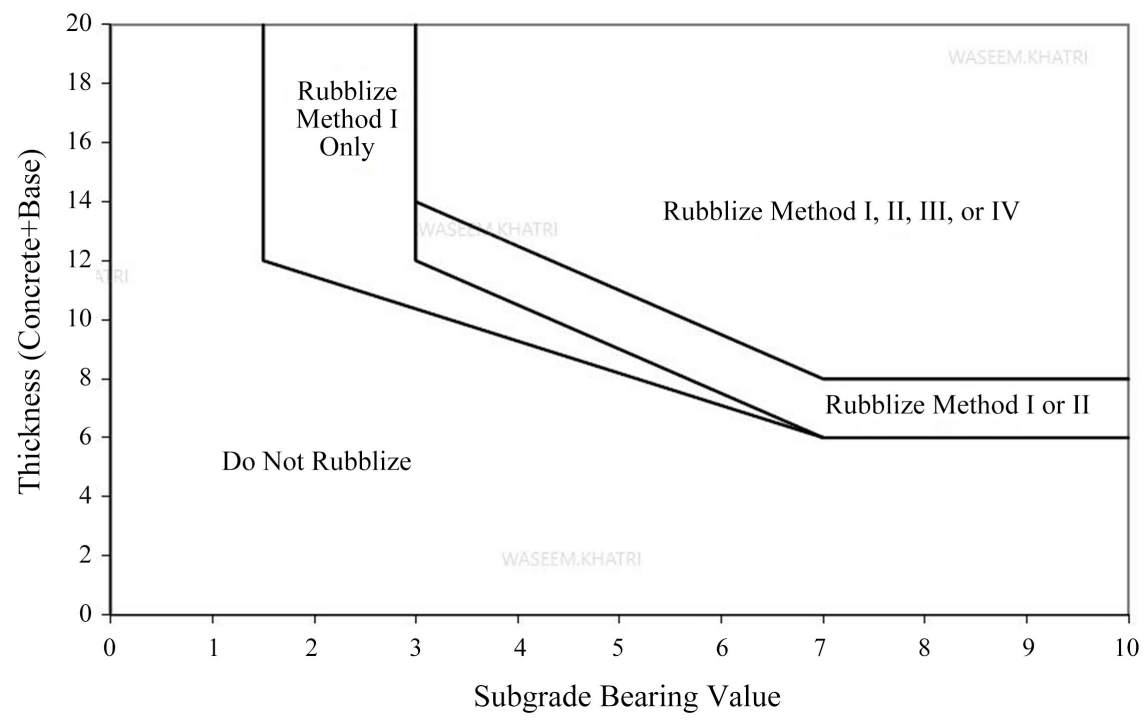

Figure 10. Illinois DOT rubblization type selection guide [8].

CBR values were determined using DCP (Dynamic Cone Penetration) tests as per ASTM 6951. The value of the subgrade CBR was more than $90 \%$ and also the thickness of the concrete slab including the aggregate base course came to 530 $\mathrm{mm}$ (21 inches), which allows pavement to be rubblized.

As per FAA 150/5320/6F [10], a modulus value $348 \mathrm{~N} / \mathrm{mm}^{2}$ was chosen. FAA $150 / 5320 / 6 \mathrm{~F}$ suggests following range of rubblization modulus to be adopted for different thicknesses.

- For slabs 6 to 8 inches thick: Moduli from 100,000 $\left(689 \mathrm{~N} / \mathrm{mm}^{2}\right)$ to 135,000 psi $\left(930 \mathrm{~N} / \mathrm{mm}^{2}\right)$;

- For slabs 8 to 14 inches thick: Moduli from 135,000 $\left(930 \mathrm{~N} / \mathrm{mm}^{2}\right)$ to 235,000 psi $\left(1620 \mathrm{~N} / \mathrm{mm}^{2}\right)$;

- For slabs greater than 14 inches thick: Moduli from 235,000 (1620) to $400,000 \mathrm{psi}\left(2757 \mathrm{~N} / \mathrm{mm}^{2}\right)$.

The chosen value was slightly conservative when compared with the FAA $150 / 5320 / 6 \mathrm{~F}$ guidance but this was adopted to avoid the need for redesign after the rubblization is completed as this will impact not only the change in pavement section thickness but can also impact the finished grade levels. The actual value achieved through Heavy Weight Heavy weight Deflectometer (HWD) site testing achieved was between 402 to $737 \mathrm{~N} / \mathrm{mm}^{2}$. The average modulus value was approximately $500 \mathrm{~N} / \mathrm{mm}^{2}$.

The pavement analysis was completed in accordance with FAA AC 150/5320-6F and using the software FAARFIELD [11] [12].

The following selected design parameters deduced from the geotechnical and Pavement investigations were used:

- Design subgrade, for new pavement area $\mathrm{CBR}=6 \%, \mathrm{~K}=18 \mathrm{MN} / \mathrm{m}^{2} / \mathrm{m}$.

- Existing subgrade improvement of $300 \mathrm{~mm}$ with stiffness modulus of $250 \mathrm{MPa}$ has been used. This was modelled as a user defined layer in FAARFIELD. 
- Existing PCC modulus of rupture-4.83 N/ $\mathrm{mm}^{2}$.

- Existing PCC Structural Condition Index (SCI)-67.

Other selected design parameters:

- $\mathrm{P} / \mathrm{TC}$ ratio $=1$, (aircraft do not taxi along the runway prior to take-off).

- Traffic data: Total departures 2016: 1560.

- Growth Factor: 3\%.

- Design Traffic: 1560 of the B737-800 aircraft.

- Runway heading split: 50\% 09 end and 50\% 27-end.

Information on air traffic is a fundamental input for a structural analysis and design of rehabilitation measures. Based on the traffic figures supplied the following input for the structural analysis has been used:

Total departures 2016: 1560;

Aircraft mix: B737-800: 1560;

Runway usage: 09 -end $50 \%$ and 27 -end $50 \%$.

The chosen pavement analysis period was 20 years (2017-2037).

Analysis using FAARFIELD is shown in Figure 11. The total rubblized concrete $(300 \mathrm{~mm})$ and the existing base course $(230 \mathrm{~mm})$ thickness comes to 530 $\mathrm{mm}$ but a theoretical reduction of $50 \mathrm{~mm}$ was considered as a result of rubblization and took account of settlement. This is considered to be slightly conservative but provides additional stiffness to the pavement.

The adopted design was as following:

- 230 mm HMA asphalt overlay;

- $300 \mathrm{~mm}$ rubblized existing reinforced PCC;

- $230 \mathrm{~mm}$ existing crushed aggregate;

- Existing geotextile;

- Existing compacted dune sand.

\subsection{Tests Conducted}

Site investigation was carried out which included the DCP testing to assess the sub grade of the pavement including fives cores were taken from the entire runway pavement. The cores provided an average compressive strength of 50.36 $\mathrm{MPa}$. Table 1 below shows the elastic modulus at 2.5 and 7.5 from the runway center lines.

Table 1. Average Elastic modulus values.

\begin{tabular}{cccc}
\hline \multirow{2}{*}{ Elastic Modulus } & \multicolumn{3}{c}{ Values } \\
\cline { 2 - 4 } & E1 & E2 & E3 \\
\hline @2.5 (Centre Left) & 17,048 & 824 & 278 \\
@2.5 (Centre Right) & 18,024 & 792 & 293 \\
@7.5 (Centre Right) & 16,078 & 821 & 279 \\
@7.5 (Centre Right) & 22,074 & 941 & 327 \\
\hline
\end{tabular}




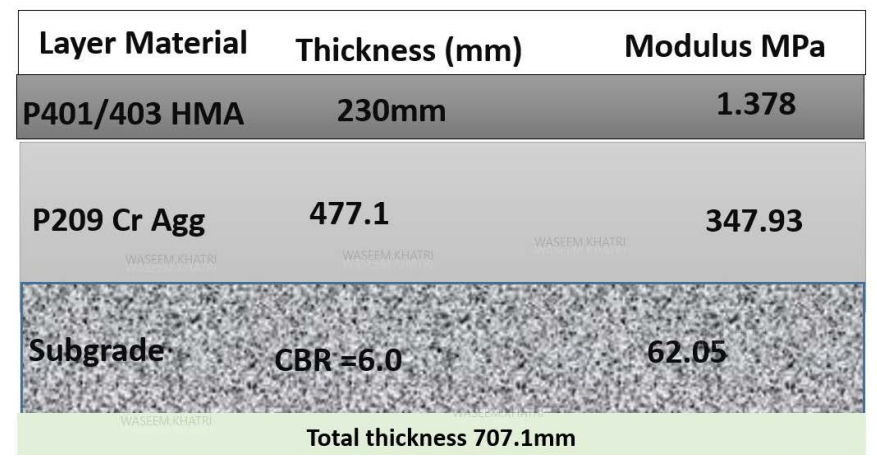

Figure 11. FAARFIELD design extract.

In addition, falling weight deflectometer testing were carried out and following Table 1 provides an average value recorded elastic modulus values of the concrete slab, unbound base and the subgrade material.

E1-Elastic Modulus of concrete pavement (MPa);

E2-Elastic Modulus of unbound aggregate base course (MPa);

E3-Elastic Modulus of subgrade combined with sub base (MPa).

After the first layer of asphalt was constructed the whole runway was assessed using heavy weight deflectometer to ensure that the rubblized values for the whole runway is within the designed $348 \mathrm{MPa}$., Whole runway was assessed and the following Figure 12 shows the achieved rubblized modulus values after construction at $3 \mathrm{~m}$ and $6 \mathrm{~m}$ from center right and left.

Hypothesis: Ceylan et al. [13] carried out an assessment of using different applications; crack and seat, break and seat and rubblization and concluded typical values to be adopted with varying slab thickness. Table 2 below shows the typical strength value expected from the crack seat, break and seat and rubblization. The adopted value of $348 \mathrm{Mpa}$ is in line with this study.

\subsection{Test Strip and Test Pits}

Before the rubblization process started, a designated test section of approximately 50 meters long by 3.6 meters wide was selected within the runway pavement. The contractor rubblize the test section using varying degrees of energy and/or various striking heights until a procedure was established that will rubblize the pavement to the required extent as contained in project specifications. The rubblized layer was visually assessed for the size of rubblized particles. After the rubblization, a test pit of 1.2 meters square was dug to determine that the breaker is producing pieces of the specified sizes as contained in the specifications. The rubblized particle sizes were checked throughout the entire depth of the pavement. The test pit material was removed from the test strip and the hole filled using aggregate base coarse material. The replacement material was placed in layers and was properly compacted.

Following Figures 13-15 below shows the test strip and the test pits pictures excavated. 
Table 2. Typical Rubblized modulus values [13].

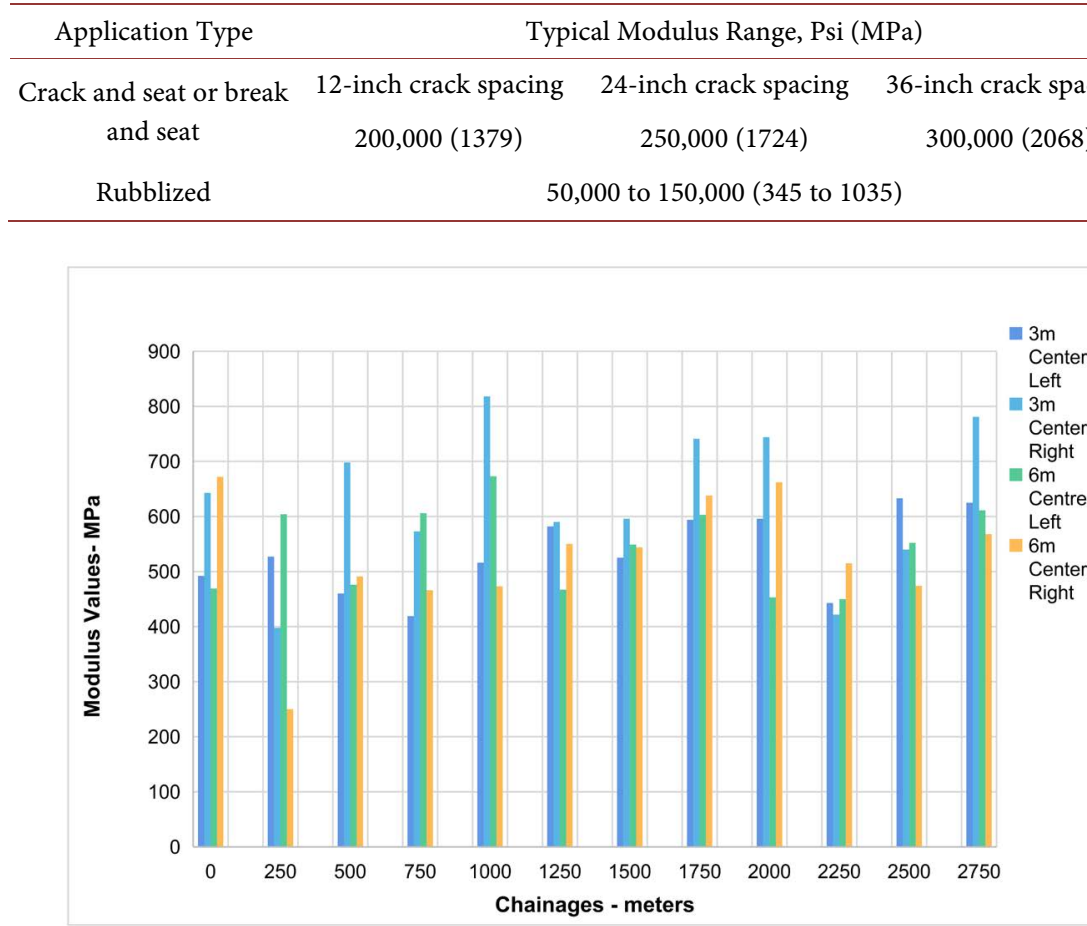

Figure 12. FAARFIELD design extract.

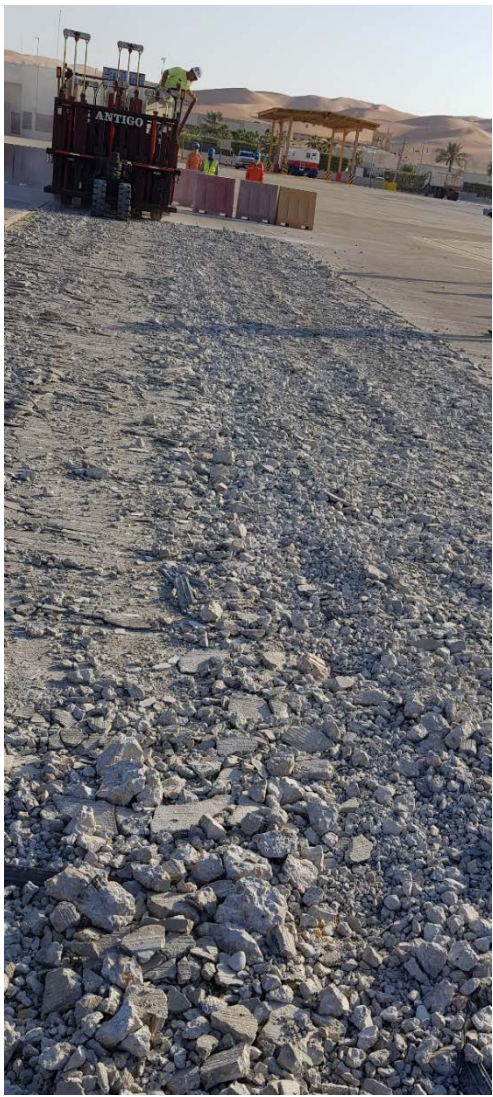

Figure 13. Test Strip. 


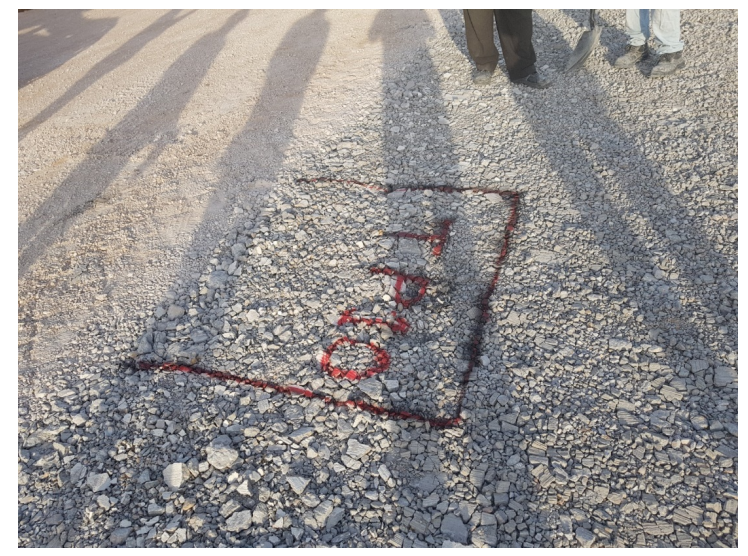

Figure 14. Test pit.

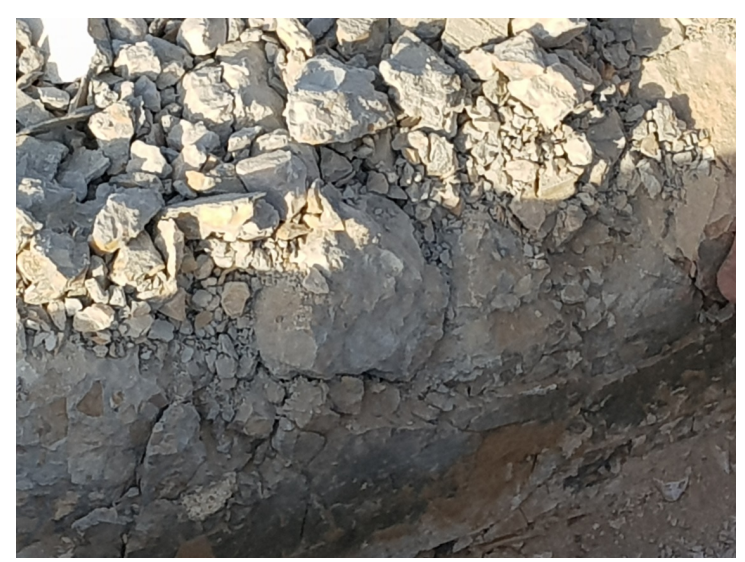

Figure 15. Excavated test pit showing fractured concrete.

\subsection{Rubblization Methodology}

For the pavement rehabilitation, guillotine and MHB (multi-head breakers) equipment were used. Guillotine breaker and multi-head breakers are shown in Figure 16 and Figure 17. The pavement was first applied with guillotine style breaker (approximately a 7-ton load) to induce full depth fractures to prepare for further fracturing using multi-head breakers (MHB). The spacing of hammer strike using guillotine breaker was approximately $500 \mathrm{~mm}$ and the height of drop was $1000 \mathrm{~mm}$ [14].

After application of the guillotine breaker, MHB was applied with a spacing of 0.5 to $1 \mathrm{~m}$ and $1000 \mathrm{~mm}$ to $1300 \mathrm{~mm}$ hammer drop height. These hammers are arranged in such a manner that their function is synced with each other.

The operator adjusts the travel speed of the MHB to match the conditions encountered throughout the project. Adjustments in hammer drop heights and travel speed are made to maintain the optimum breaking pattern. These adjustments allow the MHB to produce a wide range of breaking patterns. Larger-sized PCC segments provide increased load-carrying capacity. The travel speed of MHB was controlled and was set up at $600-700$ foot/hour to ensure continuous and uniform rubblization is carried out. 


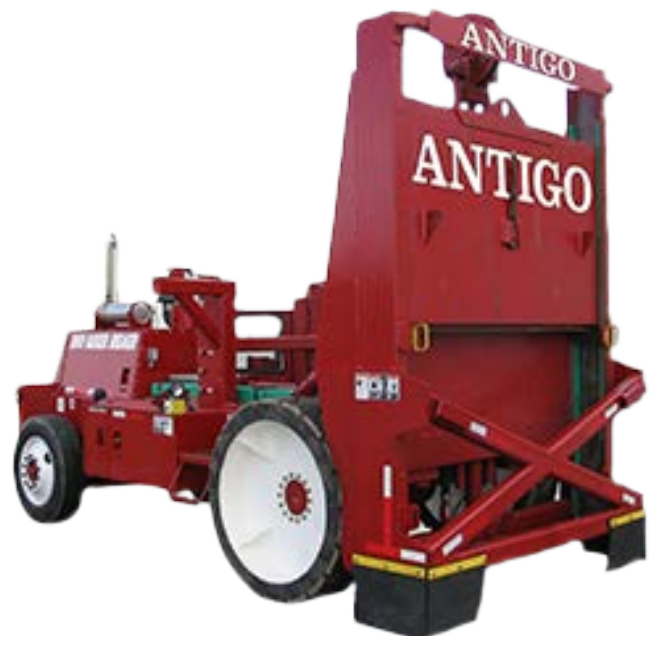

Figure 16. Guillotine Breaker (Antigo Construction) [14].

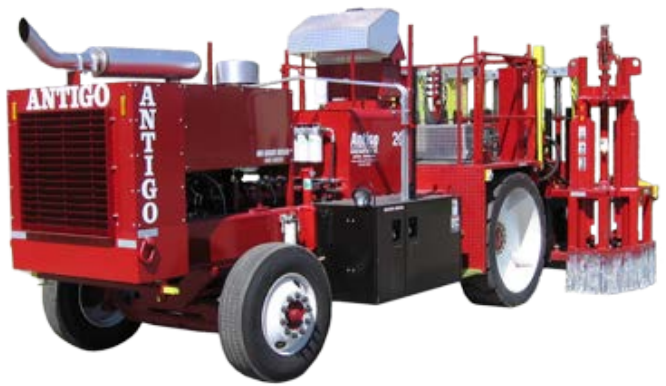

Figure 17. Multihued breakers antigo construction [15].

The MHB is a rubber-tired, self-propelled unit that carries hammers mounted laterally in pairs with half the hammers in a forward row and the remainder diagonally offset in a rear row. There is continuous breakage from side to side. Each pair of hammers is attached to a hydraulic lift cylinder that operates as an independent unit, develops varying energy depending upon drop height selected, and cycles at a rate of 30 to 35 impacts per minute. The $2.44 \mathrm{~m}$ wide machine carries 12 hammers $200 \mathrm{~mm}$ in width. A wing, carrying two hammers are 300 to $381 \mathrm{~mm}$ in width, can be added to each side for a total effective breaking width of up to $3.95 \mathrm{~m}$. The breaking energy is applied to the pavement via $38-\mathrm{mm}$ wide steel strike bars welded to the bottom of the hammers. Breaking widths can be as narrow as $0.91 \mathrm{~m}$ or increased in increments to as wide as $3.95 \mathrm{~m}$. The breaker was equipped with a screen to protect vehicles from flying debris during the fracturing process [15].

There were substantial amount of old concrete joint sealant rubber and joint dowels, reinforcement mesh, which needed to be cut and removed by hand after the rubblization as shown in Figure 18 and Figure 19. This was a labor-intensive exercise and took some time to fully clear out to ensure proper compaction is achieved and all the foreign materials is removed from the rubblized pavement before the compaction started. 
A rubblized pavement is shown in Figure 20. Once the rubblization is completed the surface is rolled using " $Z$ " grid rollers with a minimum of two passes to compact the surface as shown in Figure 21 below. After this, a further pneumatic roller is applied with a minimum of one pass to ensure the seating of all the rubblized aggregates.

Finally, a vibratory steel drum roller applied with a minimum of one pass before construction of bituminous layer. Once the rolling was completed the asphalt concrete construction was followed as normal. A prime coat was not applied due to fact that there were not sufficient amounts of fines on the surface to hold the surface together.

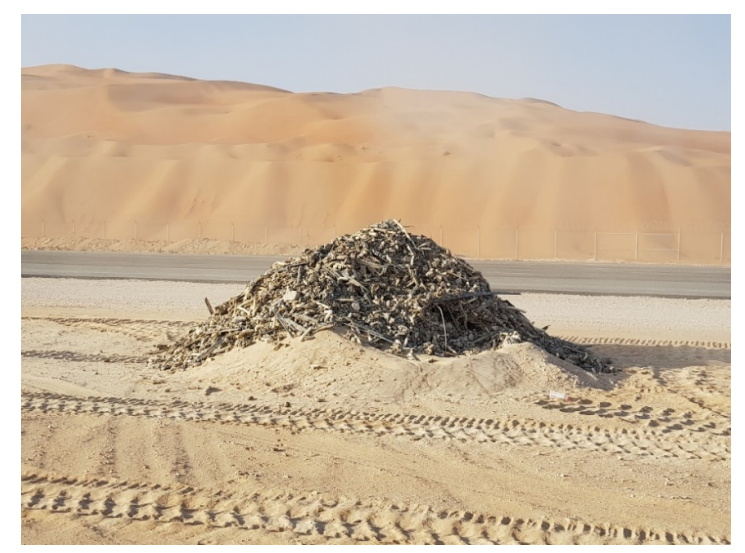

Figure 18. Heap of sealant.

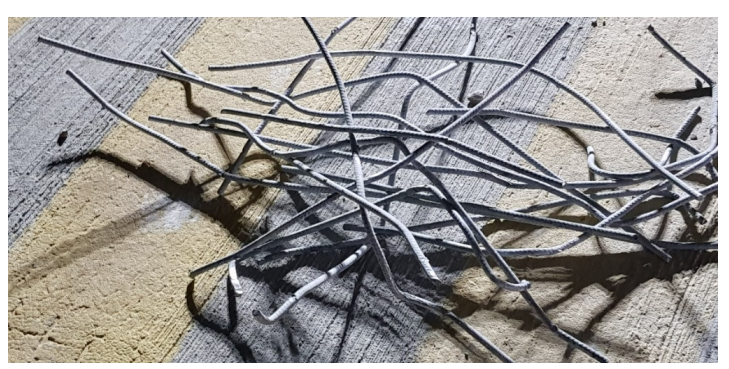

Figure 19. Reinforcement bars removed from pavement.

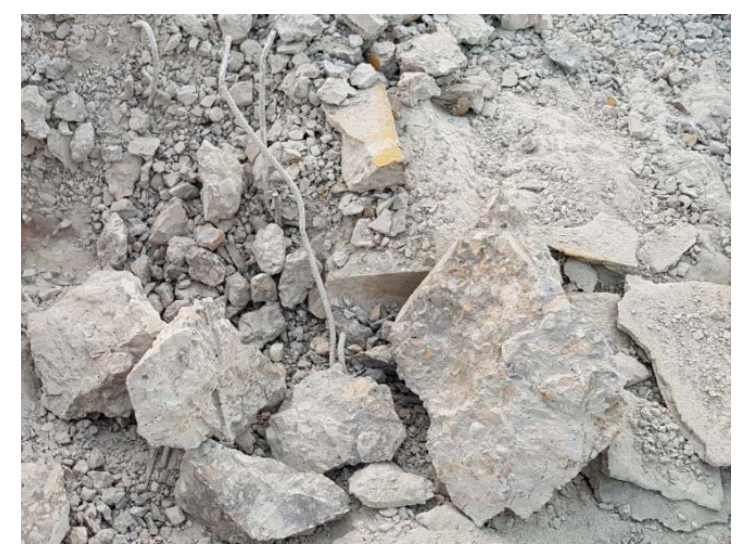

Figure 20. Rubblized concrete. 


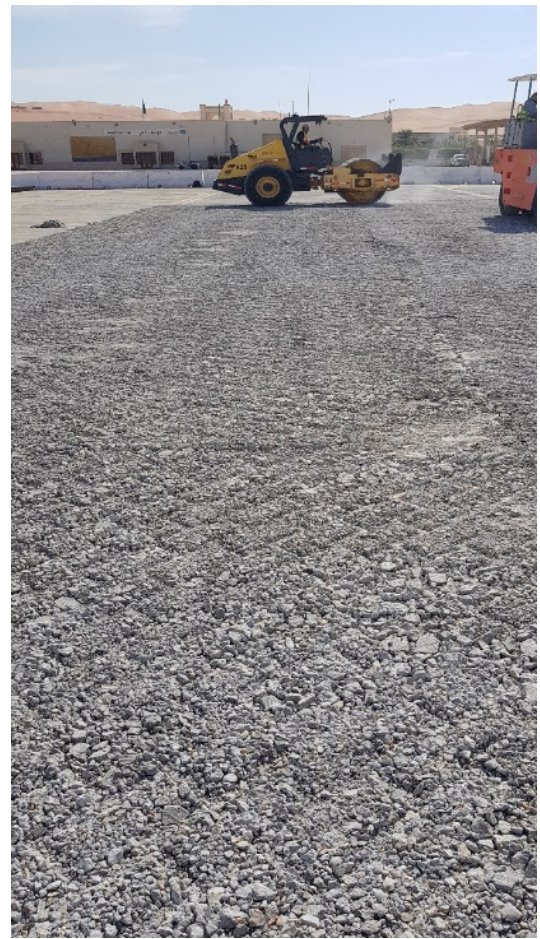

Figure 21. Roller compacted rubblized pavement.

\section{Challenges Faced and Findings}

\subsection{Following Are Some of the Challenges Faced during the Construction}

\subsubsection{Drop in Concrete Level after Rubblization}

There was an anticipation that the concrete level will drop after rubblization but it was difficult to ascertain how much will be that drop. As a result of this, a drop in $50 \mathrm{~mm}$ was assumed. But in reality, the drop was inconsistent throughout due to lower strength of concrete at the joint area and the associated settlement of the joint and the areas where there were patches. As a result, the total thickness of the pavement was in excess of $30 \mathrm{~mm}$ making the total overlay thickness of $280 \mathrm{~mm}$ at some locations. There is no indication in the FAA EB66 about the surface level drop in the pavement and this needs to be considered as this can impact the finishing levels. A drop level range to be provided to be considered within the design development.

\subsubsection{Rubblization Assessment}

FAA EB/66 does not provide details of how many pits to be dug for particular rubblized area. As a thumb rule, the project design team considered to excavate a pit every five thousand square meters. This was approximately twenty test pits for the whole project. Digging these pits were time consuming and holding up the construction progress. After observing performance of first two pits, it was decided to increase the testing from five thousand to ten thousand square meters and further assess the rubblized pavement with heavy duty defelctometer. This 
gave the opportunity to optimize the construction process and confirming the rubblization with HWD use. The FAA-EB66 guidance does not provide this detail and this is something FAA needs to look at and update. In addition, to this FAA need to provide a sieve analysis for $\%$ passing of rubblized layers to ensure that the layer gradation meets the specifications rather than relying on the visual observation only.

\subsubsection{Remoteness of the Empty Quarter, Saudi Arabia}

The Empty Quarter is a remote location in the Kingdom of Saudi Arabia. Material logistics, including getting the rubblization equipment, was a huge challenge. This was addressed by engaging a specialist rubblization contractor thorough initial consultation and understanding all the logistics requirements and time scale involved. This was addressed by arranging the visit for the specialist contractor visiting the Empty Quarter and the required spare parts and machines to account for breakdown and appropriate training for local contractors.

\subsubsection{Construction of Center Line Lighting Conduits}

The FAA allows that the conduits can be placed in the asphalt layers. But this approach could have resulted in delays to projects in cutting asphalt concrete layer for the conduit slots which were as wide as $1500 \mathrm{~mm}$ at some locations and $500 \mathrm{~mm}$ wide at the majority of the locations. Also cutting asphalt concrete creates issues with joints running in the center of the Keel area that will impact the strength of asphalt concrete in the longer run. To address this, it was decided to lay the conduits in the rubblized layer by cutting and making a slot of $100 \mathrm{~mm}$ deep as shown in Figure 22 below. The conduits were inserted in this $100 \mathrm{~mm}$ deep section and filled with asphalt concrete around it and compacted. This also ensured materials compatibility with receiving layer was asphalt concrete instead of using originally proposed controlled low strength material (CLSM). This method of construction can be added in the FAA to speed up the construction process and allow installation of conduits within the rubblized layer.

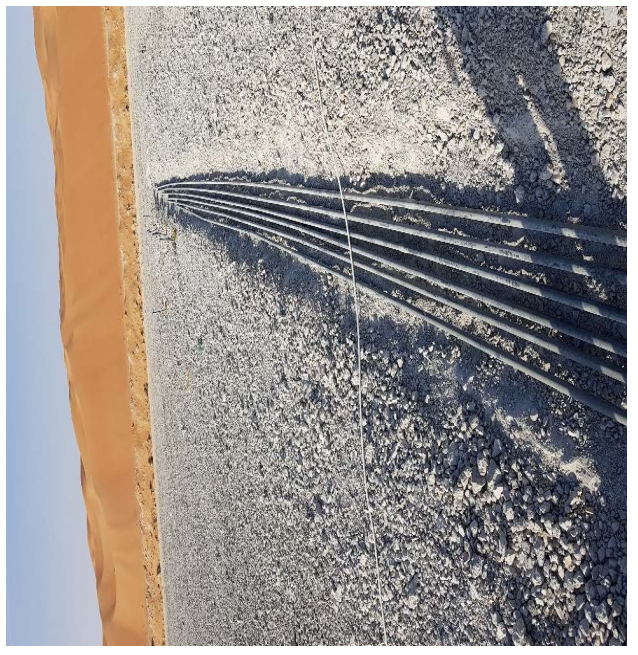

Figure 22. Conduit laid in excavated rubblized concrete. 


\subsection{Findings}

1) There are number of improvements which can be incorporated in the FAAEB 66 guidance about the quality control, level drop issue, and the fixing of conduits within the rubblized layer as demonstrated in this project.

2) During the design it's important that a realistic drop in the final construction level due to the drop in original pavement level should be considered. In this case study, a drop of $50 \mathrm{~mm}$ was considered.

3) Rubblization of existing concrete pavement needs initial assessment to ensure that the pavement can be rubblized as per Figure 10.

4) The presence of utilities can pose a dangerous situation, and it's important that all the utilities corridors are identified before rubblization begins to avoid damage and creating dangerous situations. Ideally, a clearance of $1 \mathrm{~m}$ from the utility may be sufficient to avoid any damage subject to risk assessment.

5) Test Pit-Excavation:

There were issues with the digging the test pits and it was initially difficult in the first test pit to assess the rubblization and fracturing of the pavement. To address this, the idea of using the back hoe from outside was adopted. The back hoe was positioned outside and the hoe pulled the concrete from inside to outside and this approach worked quite well with all the other ten test pits excavations.

\section{6) Presence of utilities.}

There were numbers of utilities present and in particular aviation fuel pipes running in the taxi ways. Due to this, the area around the pipeline was isolated at $1000 \mathrm{~mm}$ from each side of the pipeline to prevent damage to pipelines. This area was cut using saw cut and back filled using FAA-P209 specification aggregate base course to match with surrounding rubblized material.

\section{Conclusions}

Rubblization of concrete pavement is an ideal solution for pavement that has served its useful life and cannot be repaired further, or repairs will not provide further value to the pavement asset. Concrete pavements for airfield, highway, ports, helipads and other areas which involve aircraft or vehicular traffic can be rubblized to increase the life of existing pavements.

It is important that an initial assessment of the existing pavement is carried out to see if the pavement can be either fractured to remove the reflective cracking through crack and seat, break and seat and rubblization. Estimation of design rubblized concrete modulus is important using site investigations. Combined thickness of the existing concrete slab and aggregate base course and the subgrade strength can be used to design the overlay thickness which was demonstrated in this paper. Selection of an appropriate rubblized modulus value during the design is a key to ensure that an optimized asphalt overlay thickness is adopted based on the existing concrete pavement thickness. Quality control using HWD is important to speed up the construction process and FAA needs to 
look at providing the details of acceptable rubblized lot areas, surface level drop with varying thicknesses and the provision of utilities in the rubblized layer for ease of construction.

Present of utility can pose a challenge and the $\mathrm{H} \& \mathrm{~S}$ risk, this needs to be designed in advance during the site investigation to prevent damages to utilities and methods to work around them. Appropriate construction methods in dealing with conduits and utilities to be considered to maintain the quality of rubblized material. As highlighted in this paper, the use of PMA can address higher temperature experienced in the empty quarter of Saudi Arabia. The use of polymer modification to asphalt binder can improve the durability of pavement and also address aircraft traffic loadings.

\section{Acknowledgements}

The authors would like to thank Saudi Aramco's Consulting Services Department management and the Project Management team for providing the required information and support in publishing this paper.

\section{Conflicts of Interest}

The authors declare no conflicts of interest regarding the publication of this paper.

\section{References}

[1] Galal, K.A., Coree, B.J., Haddock, J.E., and White, T.D. (1999) Structural Adequacy of Rubblized Portland Cement Concrete Pavement. Journal of the Transportation Research Board, 1684, 172-177. https://doi.org/10.3141/1684-20

[2] Decker, D. (2006) Design and Construction Guidelines on Rubblizing and Overlaying PCC Pavements with Hot-Mix Asphalt.

https://www.semanticscholar.org/paper/Rubblization.-Design-and-Construction-G uidelines-of-Becker/02b3864ca2a876fb487ed13b4672bd8ddad69677\#paper-header

[3] Decker, D. (2006) Rubblization of Portland Cement Concrete Pavements. http://onlinepubs.trb.org/onlinepubs/circulars/ec087.pdf

[4] Gulen, S., Noureldin, A.S. and Weaver, J. (2004) Life and Cost Comparison of Three Rehabilitation Techniques on I-65 Between SR-2 and SR-114. Indiana Department of Transportation, West Lafayette. https://doi.org/10.5703/1288284313478

[5] Dhakal, N., Elseifi, M.A. and Zhang, Z. (2016) Mitigation Strategies for Reflection Cracking in Rehabilitated Pavements-A Synthesis. International Journal of Pavement Research and Technology, 9, 228-239. https://doi.org/10.1016/j.ijprt.2016.05.001

[6] Rajagopal, A. (2011) Evaluation of Rubblization Project in Ohio. Infrastructure Management and Engineering Inc., Cincinnati, $\mathrm{OH}$.

[7] Gaspard, K., Icenogle, P., Abadie, C. and Elseifi, M. (2013) Historical Performance of Rubblized Jointed Portland Cement Concrete Pavement Overlaid with Asphaltic Concrete in the State of Louisiana. International Journal of Pavement Research and Technology, 6, 165-174.

[8] Witczak, M.W. and Rada, G.R. (1992) Nationwide Evaluation Study of Asphalt 
Concrete Overlays Placed on Fractured PCC Pavements. Journal of the Transportation Research Board, Transportation Research Record 1374, 19-26.

[9] (2020) SKY Brary, UK, Foreign Object Debris (FOD). https://www.skybrary.aero/index.php/Foreign_Object_Debris_(FOD)

[10] Quintus, H. (2007) Guidance, Parameters, and Recommendations for Rubblized Pavements. https://wisconsindot.gov/documents2/research/05-07rubblization-f.pdf

[11] Federal Aviation Administration (2020) AC 150/5320-6G-Airport Pavement Design and Evaluation Document Information.

https://www.faa.gov/airports/resources/advisory_circulars/index.cfm/go/document. current/documentNumber/150_5320-6

[12] Federal Aviation Administration (2017) FAARFIELD 1.42.

https://www.airporttech.tc.faa.gov/Products/Airport-Safety-Papers-Publications/Air port-Safety-Detail/ArtMID/3682/ArticleID/4/FAARFIELD-142

[13] Ceylan. H. (2005) Rubblization of Concrete Pavement Utilizing Rubblization and Crack and Seat Methods. Center for Transportation Research and Education Iowa State University, IOWA. http://publications.iowa.gov/3548/1/rubblization.pdf

[14] Antigo Construction (2020) 8600 Badger Breaker. https://www.antigoconstruction.com/breaker-specifications/8600-badger-breaker

[15] Antigo Construction (2020) MHB Badger Breaker ${ }^{\circledR}$. https://www.antigoconstruction.com/breaker-specifications/mhb-badger-breaker 